\title{
Assessment of Undiscovered Gas Resources in the Williston Basin Province, 2020
}

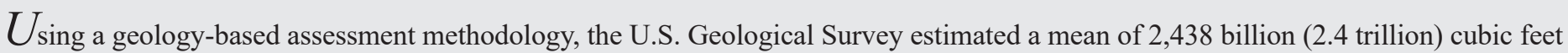
of gas resources in the Williston Basin Province, in North Dakota, Montana, and South Dakota.

\section{Introduction}

The U.S. Geological Survey (USGS) quantitatively assessed the potential for undiscovered, technically recoverable conventional and continuous gas resources in the Williston Basin Province in North Dakota, Montana, and South Dakota (fig. 1). Three geologic assessment units (AUs) were defined, one within the Ordovician Winnipeg Total Petroleum System (TPS) and two within the Upper Cretaceous-Paleogene Biogenic Gas TPS. Each AU was assessed for undiscovered gas and natural-gas liquid (NGL) resources.

The Williston Basin Province is a major petroleumproducing region. The purpose of this fact sheet is to present the potential for nonassociated conventional gas and continuous gas resources. Organic-rich shales within the Icebox Formation of the Ordovician Winnipeg Group are at a sufficient level of thermal maturity and have adequate geologic properties to host a potential shalegas accumulation. The primary key to a viable shale-gas accumulation within the Icebox Formation of the Winnipeg Group is the organic richness of the informally named Government Creek shale that forms the lower part of the Icebox Formation of the Winnipeg Group (Ulishney and others, 2005; Nesheim and Nordeng, 2013). The informal Government Creek shale contains Type I and Type II organic matter, total organic carbon (TOC) values up to 4.3 weight percent, and calculated hydrogen index values of as much as 600 milligrams hydrocarbon per gram TOC. The total thickness of the Icebox Formation of the Winnipeg Group can be more than 120 feet, but the organic-rich section is much less (Nesheim and Nordeng, 2013).

The shallow strata of the Williston Basin Province include Upper Cretaceous and Cenozoic coals, lignites, and carbonaceous shales. The organic matter in these rocks can be consumed by bacteria, thus producing shallow biogenic gas (Shurr, 1998). This process to produce biogenic gas is common across the northern Great Plains of the United States and Canada (Rice and Claypool, 1981; Shurr and Ridgley, 2002; Payenberg and others, 2003; Anna, 2010). Key assessment input data for the three AUs within the Williston Basin Province are shown in table 1.

\section{Undiscovered Resources Summary}

The USGS quantitatively assessed undiscovered conventional gas, continuous gas, and natural-gas liquid resources within the Williston Basin Province, in North Dakota, Montana, and South Dakota (table 2). The fully risked mean totals are 2,438 billion cubic feet of gas (BCFG), or 2.4 trillion cubic feet, with an F95-F5 range from 430 to 6,093 BCFG; and 100 million barrels of natural gas liquids (MMBNGL), with an F95-F5 range from 18 to 242 MMBNGL.

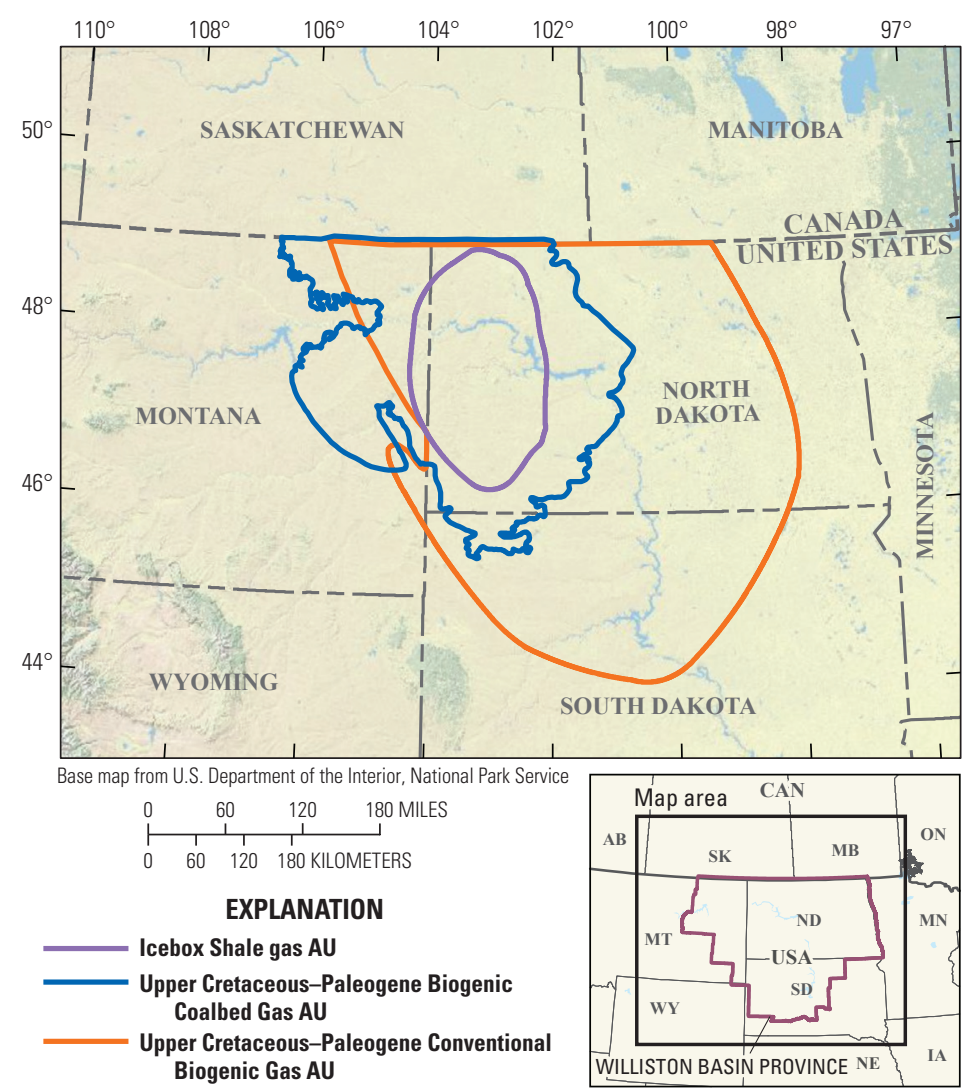

Figure 1. Map showing the location of three gas assessment units (AUs) in the Williston Basin Province, North Dakota, Montana, and South Dakota. Adjacent lines indicate a shared boundary at the outermost line. 
Table 1. Key input data for three gas assessment units in the Williston Basin Province, North Dakota, Montana, and South Dakota.

[Shading indicates not applicable. AU, assessment unit; \%, percent; EUR, estimated ultimate recovery; ; BCFG, billion cubic feet of gas]

\begin{tabular}{|c|c|c|c|c|c|c|c|c|}
\hline \multirow{2}{*}{$\begin{array}{l}\text { Assessment input data- } \\
\text { Continuous AUs }\end{array}$} & \multicolumn{4}{|c|}{ Icebox Shale Gas AU } & \multicolumn{4}{|c|}{ Upper Cretaceous-Paleogene Biogenic Coalbed Gas AU } \\
\hline & Minimum & Mode & Maximum & $\begin{array}{l}\text { Calculated } \\
\text { mean }\end{array}$ & Minimum & Mode & Maximum & $\begin{array}{l}\text { Calculated } \\
\text { mean }\end{array}$ \\
\hline Potential production area of AU (acres) & 1,000 & $1,630,000$ & $9,871,000$ & $3,834,000$ & 1,000 & $5,000,000$ & $27,370,000$ & $10,790,333$ \\
\hline Average drainage area of wells (acres) & 60 & 120 & 180 & 120 & 40 & 100 & 160 & 100 \\
\hline Area untested in $\mathrm{AU}(\%)$ & 100 & 100 & 100 & 100 & 100 & 100 & 100 & 100 \\
\hline Success ratio $(\%)$ & 10 & 50 & 90 & 50 & 2 & 7 & 15 & 8.0 \\
\hline Average EUR (BCFG) & 0.04 & 0.08 & 0.12 & 0.081 & 0.04 & 0.08 & 0 & 0.092 \\
\hline AU probability & 1 & & & & 1 & & & \\
\hline \multirow{2}{*}{$\begin{array}{l}\text { Assessment input data- } \\
\text { Conventional AU }\end{array}$} & \multicolumn{4}{|c|}{ Upper Cretaceous-Paleogene Conventional Biogenic Gas AU } & & & & \\
\hline & Minimum & Median & Maximum & $\begin{array}{l}\text { Calculated } \\
\text { mean }\end{array}$ & & & & \\
\hline Number of gas fields & 1 & 15 & 75 & 17.1 & & & & \\
\hline Size of gas fields (BCFG) & 3 & 6 & 800 & 16.8 & & & & \\
\hline AU probability & 1 & & & & & & & \\
\hline
\end{tabular}

Table 2. Results for three gas assessment units in the Williston Basin Province, North Dakota, Montana, and South Dakota.

[Results shown are fully risked estimates. F95 represents a 95-percent chance of at least the amount tabulated; other fractiles are defined similarly. Shading indicates not applicable. BCFG, billion cubic feet of gas; NGL, natural gas liquids; MMBNGL, million barrels of natural gas liquids]

\begin{tabular}{|c|c|c|c|c|c|c|c|c|c|c|}
\hline \multirow{3}{*}{ Total petroleum systems and assessment units (AUs) } & \multirow{3}{*}{$\begin{array}{c}\text { AU } \\
\text { prob- } \\
\text { ability }\end{array}$} & \multirow{3}{*}{$\begin{array}{l}\text { Accum- } \\
\text { ulation } \\
\text { type }\end{array}$} & \multicolumn{8}{|c|}{ Total undiscovered resources } \\
\hline & & & \multicolumn{4}{|c|}{ Gas (BCFG) } & \multicolumn{4}{|c|}{ NGL (MMBNGL) } \\
\hline & & & F95 & F50 & F5 & Mean & F95 & F50 & F5 & Mean \\
\hline \multicolumn{11}{|c|}{ Ordovician Winnipeg Total Petroleum System } \\
\hline Icebox Shale Gas AU & 1 & Gas & 237 & 1,103 & 3,230 & 1,339 & 18 & 83 & 242 & 100 \\
\hline \multicolumn{11}{|c|}{ Upper Cretaceous-Paleogene Biogenic Gas Total Petroleum System } \\
\hline Upper Cretaceous-Paleogene Biogenic Coalbed Gas AU & 1 & Gas & 133 & 631 & 2,107 & 811 & 0 & 0 & 0 & 0 \\
\hline Total undiscovered continuous resources & & & 370 & 1,734 & 5,337 & 2,150 & 18 & 83 & 242 & 100 \\
\hline Upper Cretaceous-Paleogene Conventional Biogenic Gas AU & 1 & Gas & 60 & 221 & 756 & 288 & 0 & 0 & 0 & 0 \\
\hline Total undiscovered conventional resources & & & 60 & 221 & 756 & 288 & 0 & 0 & 0 & 0 \\
\hline Total undiscovered resources & & & 430 & 1,955 & 6,093 & 2,438 & 18 & 83 & 242 & 100 \\
\hline
\end{tabular}

\section{References Cited}

Anna, L.O., 2010, Effects of groundwater flow on the distribution of biogenic gas in parts of the northern Great Plains of Canada and United States: U.S. Geological Survey Scientific Investigations Report 2010-5251, 24 p. [Also available at https://doi.org/10.3133/ sir20105251.]

Nesheim, T.O., and Nordeng, S.H., 2013, Examination of the Icebox Formation's (Winnipeg Group, Ordovician) source rock potential within North Dakota: North Dakota Geological Survey, Geological Investigation No. 169, 37 p.

Payenberg, T.H.D., Braman, D.R., and Miall, A.D., 2003, Depositional environments and stratigraphic architecture of the Late Cretaceous Milk River and Eagle formations, southern Alberta and north-central Montana-Relationships to shallow biogenic gas: Bulletin of
Canadian Petroleum Geology, v. 51, no. 2, p. 155-176. [Also available at https://doi.org/10.2113/51.2.155.]

Rice, D.D., and Claypool, G.E., 1981, Generation, accumulation, and resource potential of biogenic gas: American Association of Petroleum Geologists Bulletin, v. 65, no. 1, p. 5-25.

Shurr, G.W., 1998, Shallow gas play around the margins of the Williston Basin, in Christopher, J.E., Gilboy, C.F., Paterson, D.F., and Bend, S.L., eds., Eighth international Williston Basin symposium: Saskatchewan Geological Society, Special Publication No. 13, p. 129-139.

Shurr, G.W., and Ridgley, J.L., 2002, Unconventional shallow biogenic gas systems: American Association of Petroleum Geologists Bulletin, v. 86 , no. 11, p. 1939-1969.

Ulishney, A.J., Lefever, R.D., and Lefever, J.A., 2005, Oil and gas potential of the Icebox Formation (Ordovician): North Dakota Geological Survey, Report of Investigations No. 102, 50 p.

\section{For More Information}

Assessment results are also available at the USGS Energy website, https://www.usgs.gov/energy-and-minerals/energy-resources-program/.

\section{Williston Basin Province Assessment Team}

Christopher J. Schenk, Tracey J. Mercier, Cheryl A. Woodall, Geoffrey S. Ellis, Thomas M. Finn, Phuong A. Le, Kristen R. Marra, Heidi M. Leathers-Miller, and Ronald M. Drake II 